\title{
Proces implementace směrnice 2007/60/ES o vyhodnocování a zvládání povodňových rizik v podmínkách České republiky
}

\author{
PAVLA ŠTĚPÁNKOVÁ, JANA TEJKALOVÁ, KAREL DRBAL
}

Klíčová slova: plánování - povodně - nebezpečí - ohrožení - riziko - oblasti s významným povodňovým rizikem - mapy

\section{SOUHRN}

Směrnice EU 2007/60/ES o vyhodnocování a zvládání povodňových rizik (dále jen směrnice 2007/60/ES) si klade za cíl předejít nepríznivým dopadům povodní, nebo je omezit vypracováním plánů pro zvládání povodňových rizik. Vzhledem k tomu, že se príčiny a následky povodní v rưzných regionech Evropy liší, měly by uvedené plány zohlednit konkrétní charakteristiky oblastí, kterých se týkají, a navrhnout řešení podle potřeb a priorit těchto oblastí.

Proces implementace směrnice 2007/60/ES byl v ČR iniciován již v průběhu vlastní tvorby předpisu. Podrobným rozborem byly definovány problémové okruhy, jejichž řešení bylo zajištěno: (I) transpozicí principů směrnice do právního rádu ČR, (II) zahájením vývoje metodických nástrojů nezbytných ke splnění jednotlivých požadavků směrnice. Oba časově náročné dílčí procesy byly moderovány mezirezortní pracovní skupinou vedenou Ministerstvem životního prostředí ČR.

$\checkmark$ príspěvku jsou uvedeny principy vybraných metodických postupů včetně dosažených výsledků. Zejména se jedná o fázi vymezení oblastí s významným rizikem, metodickou podporu tvorby map povodňového nebezpečí a povodňových rizik, zpracování dokumentací oblastí s významným povodňovým rizikem a Plánů pro zvládání povodňových rizik. Dále jsou zmíněny povinnosti spojené s reportováním výsledkư jednotlivých fází implementace směrnice 2007/60/ES Evropské komisi.

\section{ÚVOD}

V souvislosti s povodňovými událostmi získali obyvatelé České republiky za posledních téměř dvacet let tragické zkušenosti, které dokládají smutné údaje: 137 obětí na lidských životech a téměř 188 mld. Kč materiálních škod. Negativní povodňové dopady vyplývají ze dvou hlavních typů povodňového nebezpečí, kterým je území České republiky vystaveno. Jedná se o povodně z regionálních deštư a povodně z prívalových srážek. Např́klad v červnu 2013 došlo ke kombinaci obou typů príčinných jevů, zejména v povodích Ohře, Berounky a horní Vltavy.

Ochraně před povodněmi je v ČR věnována velká pozornost a jsou vynakládány nemalé finanční prostředky jak v oblasti prevence, tak v rámci operativních opatření. Ochrana před negativními dopady povodní jako soubor opatření je výsledkem dlouhodobého procesu, v rámci kterého jsou po uvážení všech racionálních možností řešení zvolena ta efektivní. Za efektivní řešení je nutno chápat takové, které je ve výsledku pořízeno za únosnou cenu při minimálních negativních vedlejších účincích a za udržitelné provozní (servisní) náklady. K tomu je nutné ve fázi tvorby návrhů opatření propojit řadu informací, znalostí, výsledkư pozorování tak, aby bylo možné minimalizovat př́padné kolize zájmů, účelů a efektů. Nicméně uplatnění systémových přístupů v řešení ochrany před negativními účinky povodní a dalšími průvodními jevy vyžaduje provedení několika nezbytných logických kroků. Z obecného pohledu zmíněná posloupnost činností znamená: (I) aktuální vyjádření míry nebezpečí, (II) věrohodné vyjádření či kvantifikaci možných dopadů, (III) volbu hledisek klasifikace a kritérií výběru nezbytných k definování splnitelného cíle/cílů ochrany, (IV) návrh postupů k dosažení cílů, (V) vypracování variant srovnatelných z pohledu plnění cílů ochrany, (VI) výběr optimálního řešení. Optimem může často být kostra systému ochrany sestavené z klíčových prvků. Nalezením výsledného řešení se zcela celý postup neuzavírá, protože po následném zahrnutí obtí̌ně kvantifikovatelných hledisek či upřesnění požadavků může nastat korekce cílů a proces se vrací do kroku (II). Již byl zmíněn problém celého postupu, který spočívá ve vybalancování střetů zájmů, kolizí aktivit a zejména ve výsledné efektivní výši součtu pořizovacích a provozních nákladů. Dosažení tohoto stavu pak vyžaduje přípravu řady metodik, na základě kterých je možné objektivizovat jednotlivé kroky uvedeného postupu.

Nezbytnost propracovaných objektivních postupů posuzování míry povodňového nebezpečí, vyjádření povodňového rizika a stanovení výše možných škod, které ve výše nastíněném postupu reprezentují kroky (I) a (II), připomínala doporučení z výsledných zpráv vyhodnocení katastrofálních povodňových situací v ČR, zejména z let 1997, 2002 a 2006. Výzkum prakticky využitelných metod v podmínkách České republiky probíhal od druhé poloviny 90. let (projekty VaV/650/5/02, SP/1c2/121/07), zavádění těchto postupů do právního rámce a rutinní praxe akcelerovalo schválení směrnice 2007/60/ES v řijnu 2007. Tento právní dokument ukládá členským státům EU povinnost postupně na jejich území vyhodnotit povodňové nebezpečí, riziko a pořízené informace zpracovat do formy príslušného mapového vyjádření, a to $v$ těchto termínech:

- do 22. 12. 2011 dokončit předběžné vyhodnocení povodňových rizik,

— do 22. 12. 2013 zajistit dokončení map povodňového nebezpečí a povodňových rizik,

- do 22. 12. 2015 zajistit dokončení a zveřejnění plánů pro zvládání povodňových rizik.

O ukončení každé fáze je pak v souladu s článkem 15 směrnice 2007/60/ES informována Evropská komise do tři měsíců prostřednictvím zprávy (tzv. reportingu). Způsob reportingu je definován dokumenty, které byly vypracovány, projednány a odsouhlaseny zástupci členských států EU v rámci pracovní skupiny Povodně při Evropské komisi (Floods Working Group) a její podskupiny pro reporting v rámci směrnice 2007/60/ES (Floods Directive Reporting Drafting Group). 


\section{IMPLEMENTACE SMĚRNICE 2007/60/ES DO ZÁKONNÝCH NOREM V ČESKÉ REPUBLICE}

Splnění úkolů požadovaných směrnicí 2007/60/ES znamenalo iniciaci procesu její implementace do právního prostředí a institucionálního rámce České republiky již od druhé poloviny roku 2007 v gesci Ministerstva životního prostředí ČR (dále jen MŽP).

Zásadní byla transpozice principů směrnice a terminologického aparátu do novely zákona č. 254/2001 Sb., o vodách a o změně některých zákonů (vodní zákon) zákonem č. 150/2010 Sb. s účinností od 1. 8. 2010. Druhým právním předpisem, který úzce souvisí se směrnicí o vyhodnocování a zvládání povodňových rizik, je nová vyhláška č. 24/2011 Sb., o plánech povodí a plánech pro zvládání povodňových rizik (účinnost od 4. 3. 2011). Vyhláška uvádí způsob a formu zpracování predběžného vyhodnocení povodňových rizik, obsah a způsob zpracování map povodňového nebezpečí, map povodňových rizik a formy jejich zveřejnění, obsah a způsob zpracování plánů povodí a plánů pro zvládání povodňových rizik a konečně zpưsob zpřístupnění prípravných prací, návrhư plánů pro aktivní zapojení veřejnosti.

\section{Koordinace procesu}

Koordinaci procesu plánování v oblasti vod (tj. proces plánování podle směrnice 2007/60/ES i směrnice 2000/60/ES - Rámcová směrnice o vodách) na národní úrovni zajištuje Komise pro plánování v oblasti vod (dále jen KPOV). KPOV je poradním orgánem úřadů veřejné správy a dalších institucí pro koordinaci zpracování plánů povodí a plánů pro zvládání povodňových rizik pro prípravu dalšího plánovacího období. Plány povodí a plány pro zvládání povodňových rizik jsou rovnocennými dokumenty, které jsou zpracovávány pro jednotlivá dílčí povodí. Jejich príprava je vzájemně koordinována včetně časového harmonogramu procesních záležitostí (zveřejnění, termíny připomínkovacích procesů atd.).

Pro koordinaci aktivit při implementaci Povodňové směrnice působila v letech 2008-2016 pracovní podskupina Povodňová směrnice, která podporovala rozhodování príslušných ministerstev v oblasti zvládání povodňového rizika. Základní podskupina měla dvanáct stálých členů, kterými jsou zástupci ministerstev, Českého hydrometeorologického ústavu, Výzkumného ústavu vodohospodářského T. G. Masaryka a správců všech povodí ČR. V polovině roku 2016 byla skupina nahrazena Pracovním výborem pro implementaci Povodňové směrnice $v$ rámci nové struktury KPOV pro třetí plánovací období. Pracovní výbor má obdobnou strukturu a shodné kompetence jako předchozí skupina.

V rámci pracovní podskupiny i pracovního výboru je zřízena širší platforma, která zahrnuje ještě zástupce všech krajských odborů životního prostředí (vodoprávní orgány), odborů krizového řízení a odborů územního rozvoje. Rozšiřený pracovní výbor pro implementaci Povodňové směrnice má 40 členů a setkává se zpravidla jedenkrát ročně, vyjadřuje se k postupu implementace a projednává podněty ze svého regionu.

\section{DEFINICE POJMU゚}

Povodňové nebezpečí - charakterizuje stav s potenciálem způsobit nežádoucí následky (povodňové škody) v záplavovém území. Povodňové nebezpečí Ize definovat také jako "hrozbu“ události (povodně), která vyvolá např. ztráty na lidských životech, škody na majetku, prírodě a krajině. Povodňové nebezpečí může být kvantifikováno pomocí hodnot základních charakteristik průběhu povodně (hloubka, rychlost).

Zranitelnost území - vlastnost území, která se projevuje jeho náchylností k poškození a škodám $v$ důsledku malé odolnosti vưči extrémnímu zatížení povodní, tj. v důsledku tzv. expozice.
Povodňové ohrožení - je vyjádřeno jako kombinace pravděpodobnosti výskytu nežádoucího jevu (povodně) a nebezpečí. Zásadní rozdíl mezi povodňovým ohrožením a povodňovým rizikem spočívá v tom, že ohrožení není vázáno na konkrétní objekty v záplavovém území (Zú) s definovanou zranitelností. Ohrožení je možné vyjádřit plošně pro celé Zú bez ohledu na to, co se v něm nachází. V okamžiku, kdy ohrožení vztáhneme ke konkrétnímu objektu $\checkmark$ ZÚ s definovanou zranitelností, začíná představovat povodňové riziko. V rámci metody matice rizika je povodňové ohrožení vyjádřeno jako funkce pravděpodobnosti výskytu daného povodňového scénáře a tzv. intenzity povodně.

Povodňové riziko - je vyjádřeno nejčastěji jako kombinace pravděpodobnosti výskytu nežádoucího hydrologického jevu (povodně, scénáře nebezpečí) a jeho nepřiznivých dopadů na lidské zdraví, životní prostředí, kulturní dědictví a hospodářskou činnost.

\section{PŘEDBĚŽNÉ VYHODNOCENÍ POVODŇOVÝCH RIZIK}

Stěžejním cílem predběžného vyhodnocení povodňových rizik v České republice bylo vybrat na základě co nejširšího plošného posouzení povodněmi ohrožených území takové oblasti, kde jsou povodňová rizika významná a pro které je žádoucí a současně i reálně možné připravit plány pro zvládání povodňových rizik, a to na základě zpracování map povodňového nebezpečí a map povodňových rizik. Vedle schopnosti postihnout hodnocením co největší část území státu, kde mohou existovat povodňová rizika, je tedy podstatným požadavkem na použitou metodiku i nabídnout co nejobjektivnější kritéria pro stanovení významnosti rizik při potřebě porovnat i oblasti s velmi rozdílnými podmínkami fyzicko-geografickými, s rozdílným využitím území a s výraznými rozdíly v míre ohrožení povodňovým nebezpečím.

Z uvedeného vyplývá, že základní otázkou pro nastartování procesu předběžného vyhodnocení povodňových rizik bylo exaktní vymezení obsahu sousloví „významné povodňové riziko". Směrnice 2007/60/ES vyžaduje, aby tento proces byl založen na dostupných nebo snadno odvoditelných informacích a aby byl opakovatelný v šestiletých plánovacích cyklech. Současně ponechává definici „významnosti“ na každém z členských států EU.

K předběžnému vyhodnocení povodňových rizik $v$ České republice byly použity zásadně standardně zpracovávané databáze poskytující podklady zejména o lokalizaci a prostorovém vymezení dále uvedených prvků a způsobů využití území, popř. informace vhodné pro posouzení nebo vyhodnocení následků, ke kterým by mohlo docházet při zasažení př́slušných objektů povodněmi.

Předběžné vyhodnocení povodňových rizik bylo založeno na využití dvou základních hledisek, podle kterých Ize dopad povodňového nebezpečí kvantifikovat [1]. Základními hledisky pro výběr oblastí s významným povodňovým rizikem byly zvoleny:

- počet obyvatel pravděpodobně dotčených povodňovým nebezpečím v záplavových územích podle všech dostupných scénářů nebezpečí (zejména $\mathrm{Q}_{5^{\prime}} \mathrm{Q}_{20^{\prime}} \mathrm{Q}_{100}$ ), v průměru za rok;

- hodnota majetku v užívání více jak rok (fixní aktiva) na zastavěných plochách a príslušejícího do silniční dopravní infrastruktury pravděpodobně dotčeného povodňovým nebezpečím v záplavových územích podle všech dostupných scénářu nebezpečí (zejména $\mathrm{Q}_{5^{\prime}} \mathrm{Q}_{20^{\prime}} \mathrm{Q}_{100}$ ), $\mathrm{v}$ průměru za rok. 
Dále byla zvolena pomocná hlediska, která sloužila k upřesnění rozsahu oblastí s významným povodňovým rizikem po jejich vymezení podle základních hledisek při nastavení kritérií. Jednalo se o následující údaje:

- povodňové ohrožení objektů, ve kterých se nakládá s nebezpečnými látkami, a mají proto potenciál způsobit havarijní znečištění vody nebo životního prostředí při zasažení povodní s dobou opakování 100 let;

- povodňové ohrožení kulturních a historických památek při povodni s dobou opakování 100 let.

K vlastnímu vymezení oblastí s významným povodňovým rizikem bylo na základě testovacích analýz doporučeno použít pro základní hlediska splnění alespoň jedno z uvedených kritérií:

- počet obyvatel dotčených povodňovým nebezpečím $\geq 25$ obyv./rok,

— hodnota dotčených fixních aktiv povodňovým nebezpečím $\geq 70$ mil. Kč/rok.

Přičemž do výběru byla zahrnuta všechna území měst a obcí, ve kterých byla naplněna alespoň jedna z podmínek kombinovaného kritéria. Za primární oblast s významným povodňovým rizikem je považováno území charakterizované úsekem hlavního vodního toku vymezený územím obce, kde bylo naplněno a překročeno uvedené kritérium. $V$ prípadě, že vybrané základní územní jednotky spolu nesousedí, byly spojeny vymezené úseky do jednoho souvislejšího úseku vodního toku bud' na základě vyhodnocení pomocných hledisek, nebo s ohledem na praktickou řešitelnost hydrologických souvislostí.

\section{Výsledky předběžného vyhodnocení povodňových rizik}

Výsledkem analýz je vymezení úseků vodních toků a také seznam obcí, u kterých jsou povodňová rizika předběžně vyhodnocena jako významná a pro které byly následně zpracovávány mapy povodňového nebezpečí a povodňových rizik v rámci šestiletého cyklu prríprav plánů povodí a plánů pro zvládání povodňových rizik.

$\checkmark$ době zpracování úlohy předběžného vyhodnocení povodňových rizik byly dostupné údaje vymezených záplavových území pro 10890 km vodních toků, což představuje cca 67\% tzv. významných vodních toků (podle vyhlášky č. 178/2012 Sb.). Hlavním výstupem je přehledná mapa dílčích povodí v České republice s vyznačenými úseky vodních toků, které charakterizuji oblasti s významným povodňovým rizikem (obr. 1). Celková délka úseků významných vodních toků v oblastech, kde bylo vyhodnoceno povodňové riziko jako významné, činí 2965 km.

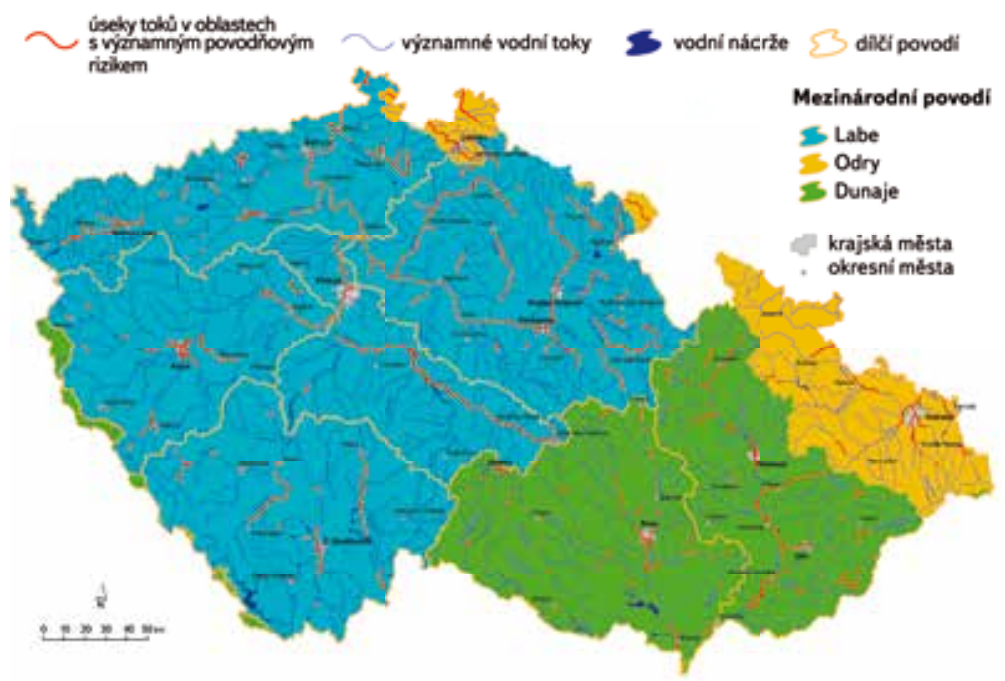

Obr. 1. Úseky vodních toků definující oblasti s významným povodňovým rizikem Fig. 1. River segments with potential significant flood risk

\section{MAPOVÁNÍ POVODŇOVÝCH RIZIK V ČESKÉ REPUBLICE}

Směrnice 2007/60/ES ukládá členským státům pevnými časovými termíny povinnost postupně na jejich území vyhodnotit povodňové nebezpečíriziko a tato vyhodnocení zpracovat do formy př́slušného mapového vyjádření. Pro tyto účely byla $\vee$ České republice připravena Metodika tvorby map povodňového nebezpečí a povodňových rizik [2], jejímž cílem je nejen plnění požadavků směrnice 2007/60/ES, ale také poskytnutí kvalitních podkladů pro kvalifikované rozhodování o využití území v rámci územního plánování i o potřebách a rozsahu opatření proti vzniku povodňových škod.

Podle zákona o vodách (150/2010 Sb., §64a) vymezují mapy povodňového nebezpečí území, která by mohla být zaplavena podle rưzných povodňových scénářů. Na mapách povodňových rizik se pak vyznačí potenciální nepríiznivé následky povodní podle těchto scénár̆ů.

Hodnocení povodňového ohrožení a povodňového rizika záplavových území je prováděno pomocí tzv. metody matice rizika. Tato metoda je jedním z nejjednodušších postupů pro hodnocení potenciálního ohrožení a rizika v záplavových územích. Metoda nevyžaduje kvantitativní odhad škody způsobené vybřežením vody z koryta, ale vyjadřuje povodňové riziko pomocí zvolených kategorií. Postup metody spočívá v následujících krocích:

- kvantifikace povodňového nebezpečí - výpočet intenzity povodně na základě hloubek a rychlostí,

- stanovení povodňového ohrožení pomocí matice rizika,

— určení ploch s nepřijatelným rizikem.

\section{Mapy povodňového nebezpečí}

Tyto mapy zobrazují tři základní charakteristiky povodně, a to její rozsah (rozliv), hloubky zaplavení a rychlosti proudění (obr.2a-2c) pro zvolené povodňové scénáře (standardně pro doby opakování 5, 20, 100 a 500 let). Scénáŕ nebezpečí schematicky nebo modelově ilustruje potenciální rozsah události mající za následek škody.

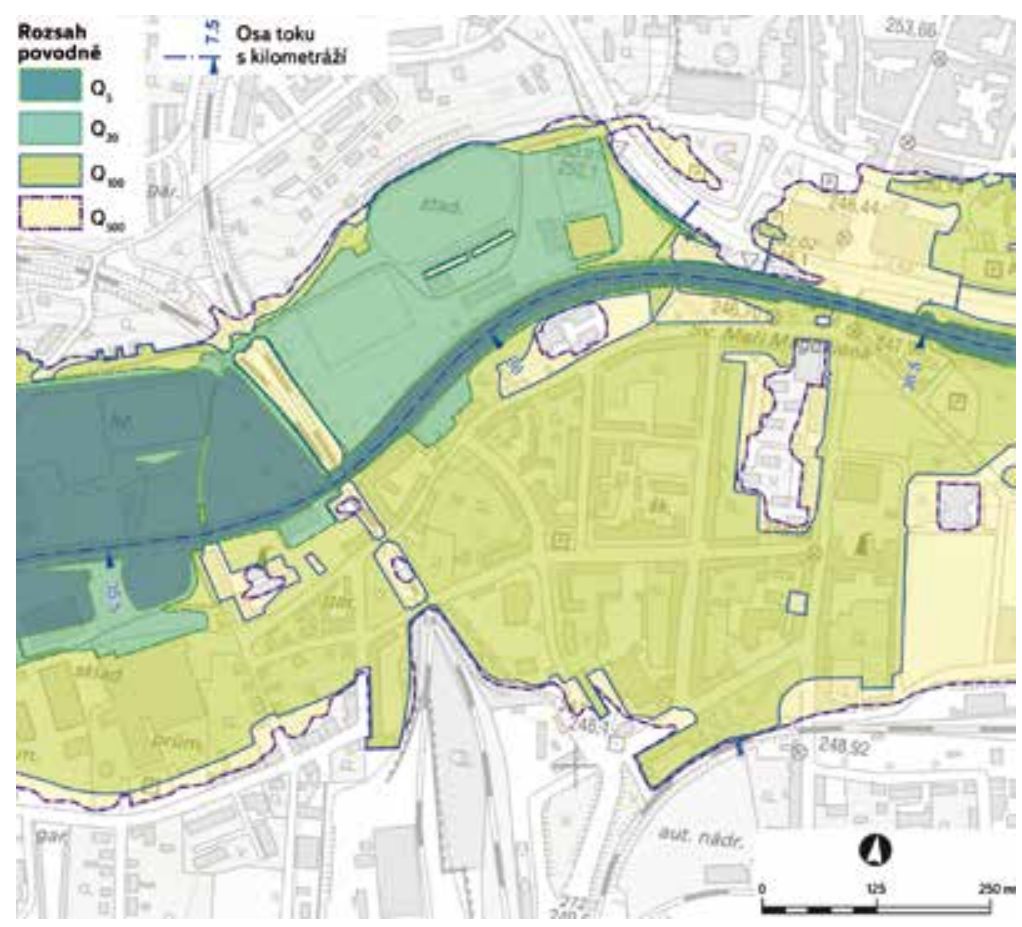

Obr. 2a. Mapa rozsahu povodně s dobou opakování 5, 20, 100 a 500 let $\left(Q_{5^{\prime}} Q_{20^{\prime}} Q_{100^{\prime}} Q_{500}\right)$ Fig. 2a. Flood extent map for return period 5, 20, 100 a 500 years $\left(Q_{5^{\prime}} Q_{20^{\prime}} Q_{100^{\prime}} Q_{500}\right)$ 


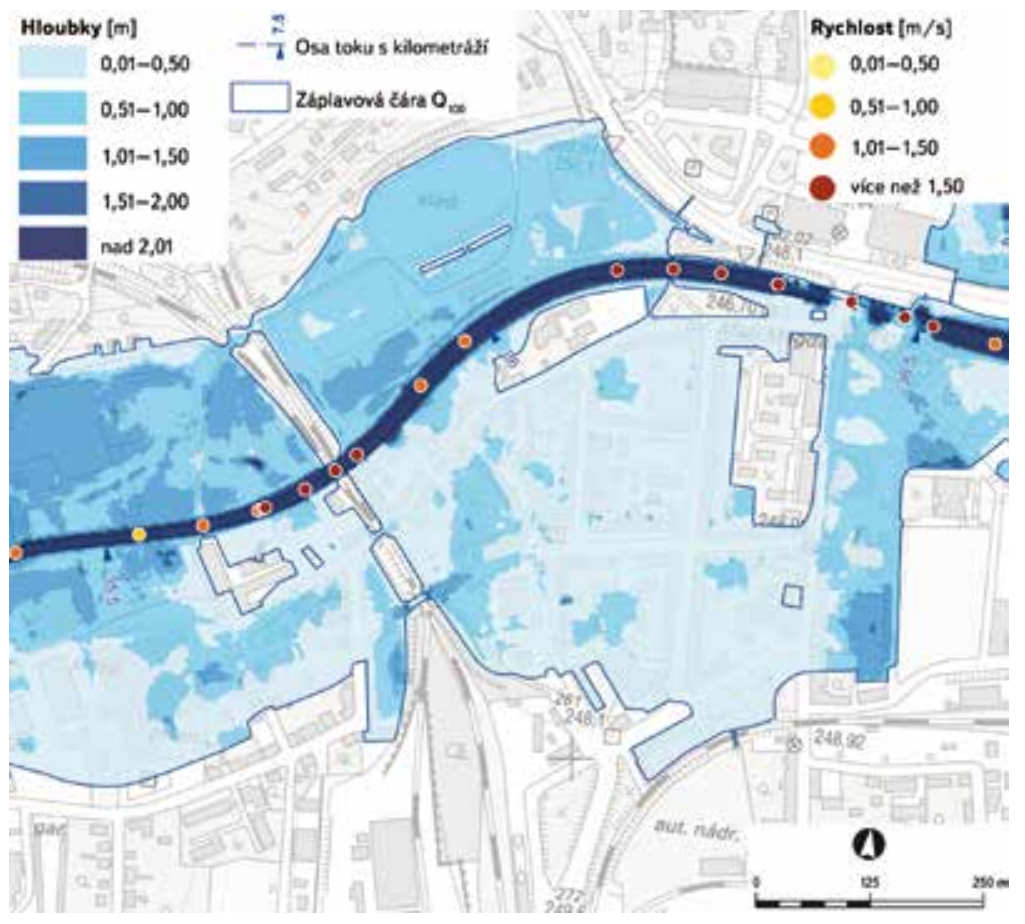

Obr. 2b. Mapa hloubek a bodových rychlostí (výstup 1D modelu) pryi scénári s dobou opakování 100 let $\left(\mathrm{Q}_{100}\right)$

Fig. 2b. Water depth and flow velocity map (1D model output) for flood with return period 100 years $\left(\mathrm{Q}_{100}\right)$

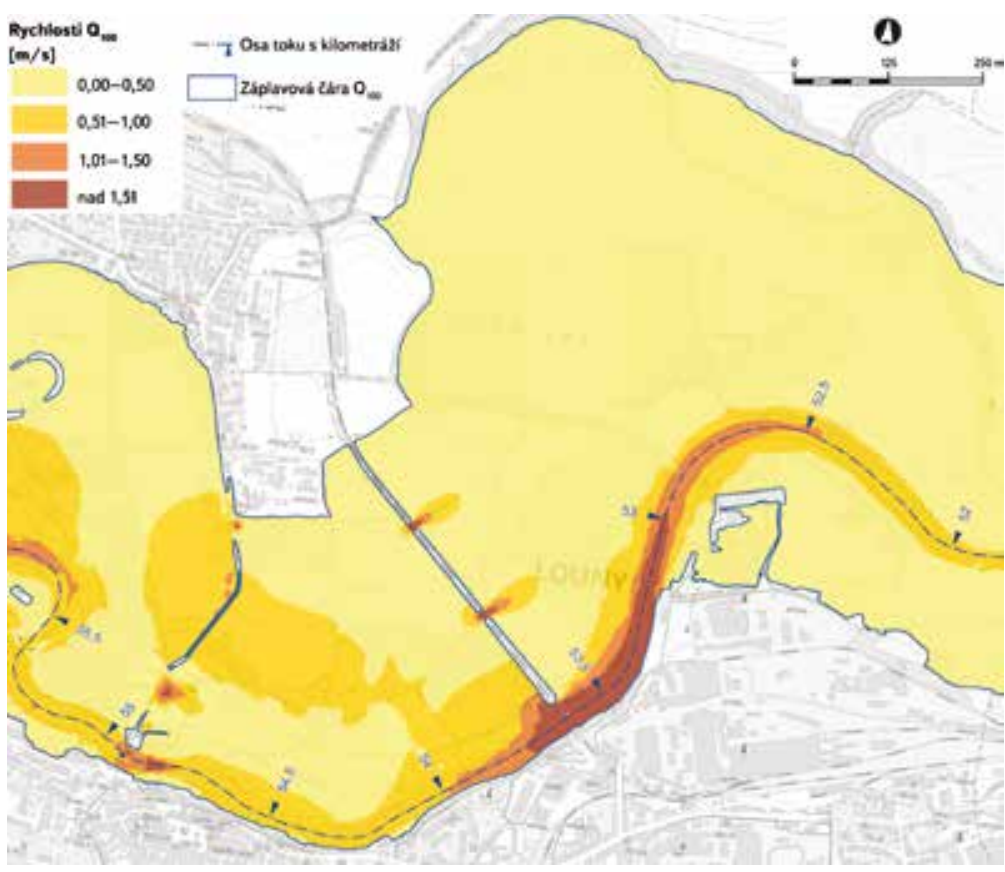

Obr. 2c. Mapa rychlostí pro povodňový scénářs dobou opakování 100 let $\left(Q_{100}\right)$ - výstup z 2D hydraulického modelu

Fig. 2C. Flow velocity map for flood with return period 100 years $\left(Q_{100}\right)$ - output of $2 D$ mode

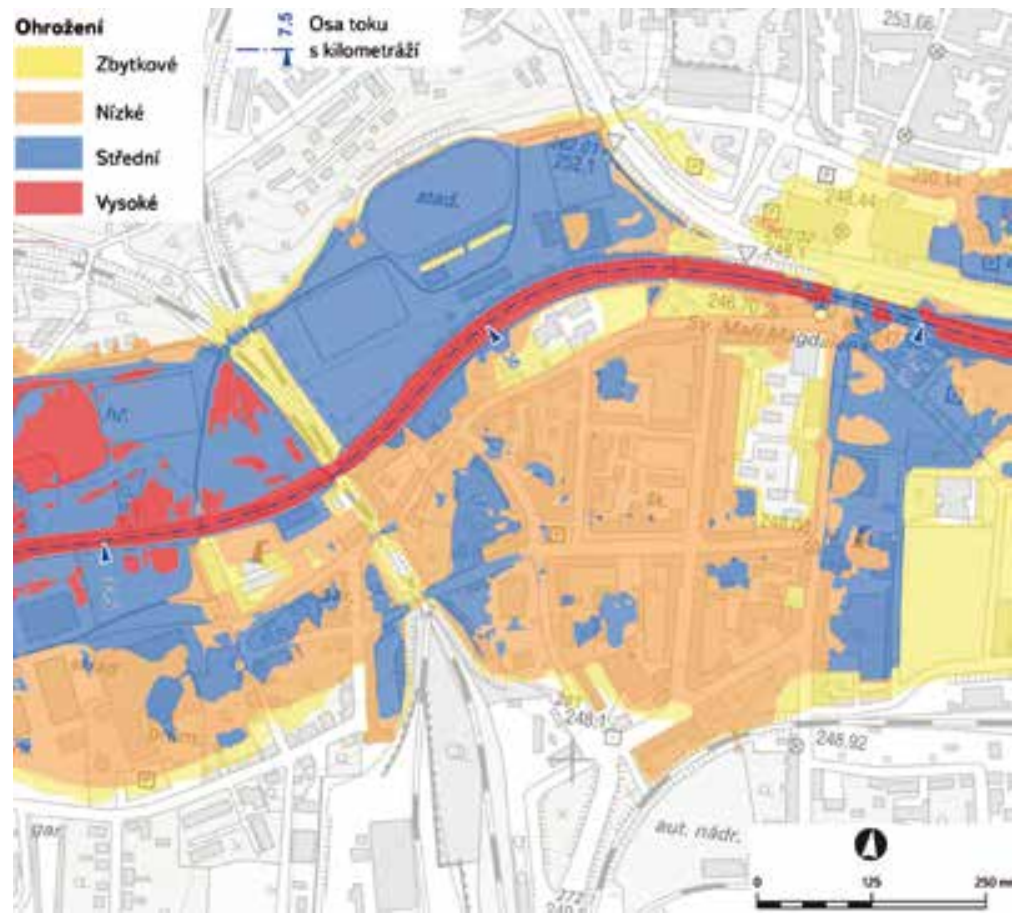

Obr. 3. Mapa povodňového ohrožení

Fig. 3. Map of flood threat

Tabulka 1. Kategorie ohrožení a doporučená pravidla pro využití území do nich spadající Table 1. Categories of flood threat and recommendation of land-use

\begin{tabular}{|c|c|}
\hline Kategorie ohrožení & Doporučení \\
\hline $\begin{array}{l}\text { (4) Vysoké } \\
\text { (červená barva) }\end{array}$ & $\begin{array}{l}\text { Doporučuje se nepovolovat novou ani neroz- } \\
\text { šiřovat stávající zástavbu, ve které se zdr- } \\
\text { žují lidé nebo umístují zvířata. Pro stávající } \\
\text { zástavbu je třeba provést návrh povodňo- } \\
\text { vých opatření, která zajistí odpovídající sní- } \\
\text { žení rizika, nebo zpracovat program vymís- } \\
\text { tění této zástavby. }\end{array}$ \\
\hline $\begin{array}{l}\text { (3) Střední } \\
\text { (modrá barva) }\end{array}$ & $\begin{array}{l}\text { Výstavba je možná s omezeními vycháze- } \\
\text { jícími z podrobného posouzení nezbyt- } \\
\text { nosti funkce objektů v ohroženém území } \\
\text { a z potenciálního ohrožení objektư povod- } \\
\text { ňovým nebezpečím. Nevhodná je výstavba } \\
\text { citlivých objektů (např. zdravotnická zařízení, } \\
\text { hasiči apod.). Nedoporučuje se rozšiřovat stá- } \\
\text { vající plochy určené pro výstavbu. }\end{array}$ \\
\hline $\begin{array}{l}\text { (2) Nízké } \\
\text { (oranžová barva) }\end{array}$ & $\begin{array}{l}\text { Výstavba je možná, přičemž vlastníci dotče- } \\
\text { ných pozemků a objektů musí být upozor- } \\
\text { něni na potenciální ohrožení povodňovým } \\
\text { nebezpečím. Pro citlivé objekty je třeba při- } \\
\text { jmout speciální opatření, např. traumatolo- } \\
\text { gický plán ve smyslu krizového řízení. }\end{array}$ \\
\hline $\begin{array}{l}\text { (1) Zbytkové } \\
\text { (žlutá barva) }\end{array}$ & $\begin{array}{l}\text { Otázky spojené s povodňovou ochranou } \\
\text { se zpravidla doporučuje řešit prostřednic- } \\
\text { tvím dlouhodobého územního plánování se } \\
\text { zaměřením na zvláště citlivé objekty (zdra- } \\
\text { votnická zařízení, památkové objekty apod.). } \\
\text { Snahou je vyhýbat se objektům a zařízením } \\
\text { se zvýšeným potenciálem škod. }\end{array}$ \\
\hline
\end{tabular}




\section{Mapa povodňového ohrožení}

Povodňové ohrožení je vyjádřeno jako kombinace pravděpodobnosti výskytu nežádoucího jevu (povodně) a nebezpečí. Stanovuje se ve čtyřech kategoriích plošně pro celé zaplavované území bez ohledu na to, jaká aktivita se v něm nachází (obr. 3). Pro každou z těchto kategorií existují doporučená pravidla, jak území využívat (tabulka 1). Členění území podle míry povodňového ohrožení umožňuje posoudit vhodnost stávajícího nebo budoucího funkčního využití ploch a doporučit omezení prípadných aktivit na plochách v zaplavovaném území s vyšší mírou povodňového ohrožení.

Tato mapa je důležitým podkladem pro proces územního plánování. Návrhy na využití ploch v souladu s doporučeními v tabulce 1 minimalizují prípadné povodňové škody v budoucnu.

\section{Mapa povodňového rizika}

Rozdíl mezi povodňovým ohrožením a povodňovým rizikem spočívá v tom, že ohrožení není vázáno na konkrétní objekty (aktivity) v zaplavovaném území. Každý objekt (aktivita) v zaplavovaném území je do určité míry zranitelný/odolný vůči projevům povodňového nebezpečí. Jinou míru zranitelnosti bude mít železobetonová stavba a jinou stavba s dřevěnou konstrukcí. V okamžiku, kdy ohrožení vztáhneme ke konkrétnímu objektu v zaplavovaném území s definovanou zranitelností, hovoříme o možném povodňovém riziku.

Mapa povodňového rizika vzniká kombinací informací o povodňovém ohrožení a zranitelnosti objektů (ploch využití území). Využití území se stanovuje především na základě územního plánu, popř. pomocí dalších podkladů, jako je geodatabáze ZABAGED, ortofoto mapy či terénní průzkum.

Pro potřeby sestavení mapy povodňového rizika je využití území rozděleno do osmi kategorií: bydlení, smíšené plochy (bydlení + občanská vybavenost + drobná výroba), občanská vybavenost, technická vybavenost, doprava, výroba a skladování, rekreace a sport, zeleň.

Toto rozdělení odpovídá vymezení ploch s rozdílným způsobem využití podle § 4 až § 19 vyhlášky č. 501/2006 Sb., o obecných požadavcích na využívání území. Podobně jako v územním plánu jsou plochy, které vyjadřují kategorie zranitelnosti území, řešeny ve třech časových aspektech (ne nutně jsou u všech ploch využity všechny aspekty). Tyto odpovídají současnému stavu, návrhovým plochám a plochám výhledovým. Plochy využití území jsou vymezeny na základě územních plánů, které vycházejí z katastrálních map.

Povodňové riziko se stanovuje průnikem informací o povodňovém ohrožení a zranitelnosti území. Pro jednotlivé kategorie zranitelnosti území je stanovena míra príijatelného ohrožení (tabulka 2). Mapy povodňového rizika pak zobrazují plochy jednotlivých kategorií využití území, u kterých je překročena míra tohoto přijatelného ohrožení (obr. 4). Uvnitř každé takové plochy jsou vyznačeny dosažené hodnoty neprijijatelného ohrožení. Takto identifikovaná území představují exponované plochy při povodňovém nebezpečí odpovídající jejich vysoké zranitelnosti. U těchto ploch je nutné další podrobnější posouzení jejich rizikovosti z hlediska zvládání rizika (snížení rizika na přijatelnou míru).

$\checkmark$ některých kategoriích zranitelnosti jsou definovány tzv. citlivé objekty, kterým je třeba v rámci posuzování míry přijatelného rizika věnovat zvýšenou pozornost. Patři sem např. objekty se zvýšenou koncentrací obyvatel se specifickými potřebami při evakuaci, objekty infrastruktury zajištujuící základní funkce území, objekty Integrovaného záchranného systému, objekty nemovitých kulturních památek a zdroje znečištění (obr. 4).

Všechny uvedené výstupy jsou zpřístupněny veřejnosti od prosince 2013 prostřednictvím webového mapového portálu tzv. Centrálního datového skladu http://cds.chmi.cz, popř. http://floodmaps.chmi.cz.

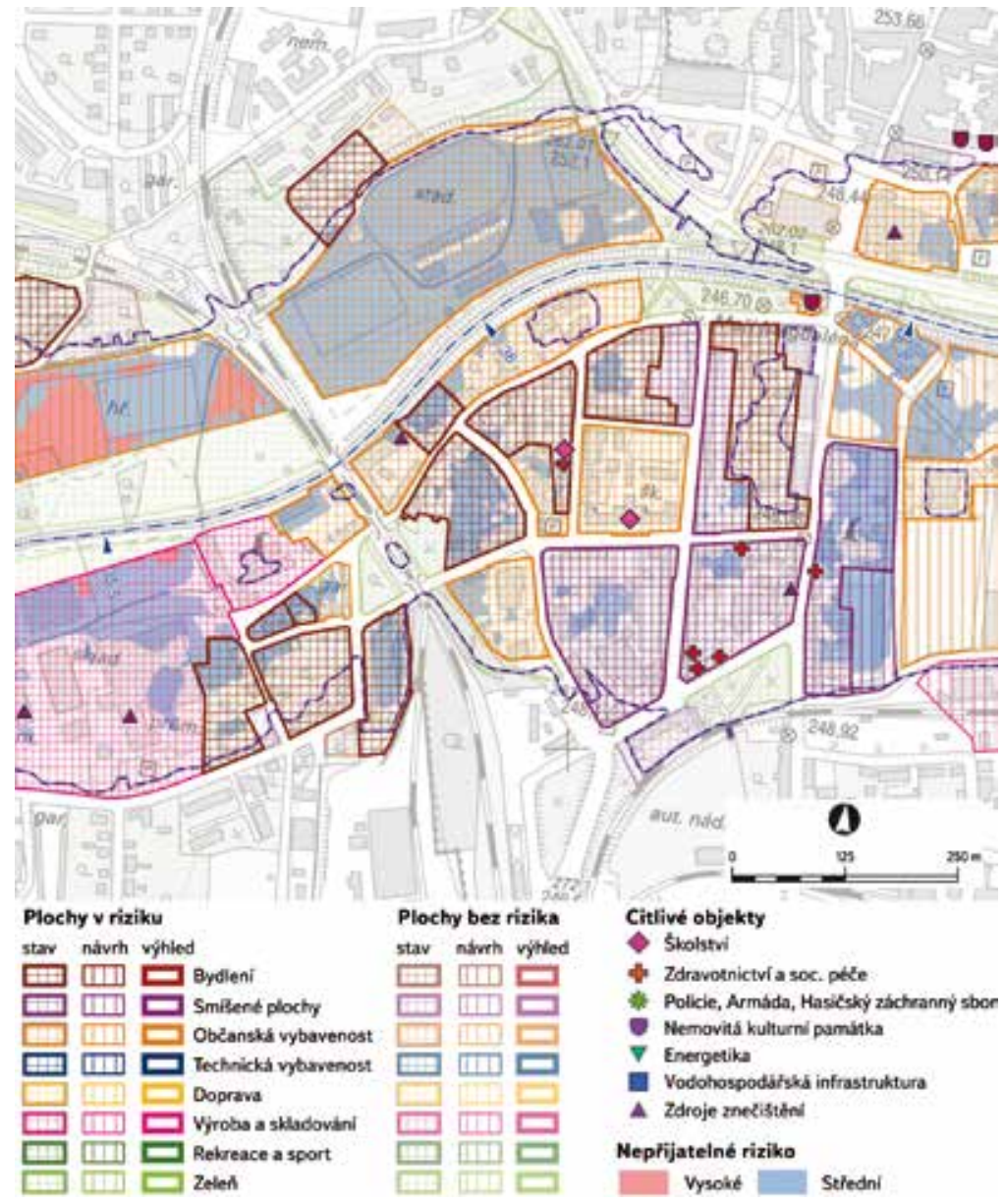

Obr. 4. Mapa povodňového rizika

Fig. 4. Flood risk map

Tabulka 2. Prijatelné ohrožení pro jednotlivé kategorie zranitelnosti území Table 2. Acceptable threat for categories of land vulnerability

\begin{tabular}{|ll|}
\hline Přijatelné riziko & Kategorie zranitelnosti území \\
\hline Vysoké & lesy, zemědělská půda, zeleň \\
\hline Střední & sport a hromadná rekreace \\
\hline Nízké & $\begin{array}{l}\text { bydlení, smíšené plochy, občanská vybavenost, } \\
\text { technická a dopravní infrastruktura, } \\
\text { výrobní plochy a sklady }\end{array}$
\end{tabular}




\section{PLÁNY PRO ZVLÁDÁNÍ POVODŇOVÝCH RIZIK}

Plánování v oblasti vod je zajištováno prostřednictvím plánů povodí a plánů pro zvládání povodňových rizik. Tyto koncepční dokumenty jsou podkladem pro výkon veřejné správy, zejména pro územní plánování a vodoprávní rízení. Plány pro zvládání povodňových rizik povodí jsou pořizovány ve dvou úrovních (obr. 5): pro mezinárodní oblasti povodí a pro části mezinárodních oblastí povodí na území České republiky (plány pro zvládání povodňových rizik [3]) Vzhledem k tomu, že Česká republika geograficky náleží ke třem mezinárodním oblastem povodí (Labe, Odra, Dunaj), jsou mezinárodní plány pro zvládání povodňových rizik připravovány $v$ rámci jednotlivých mezinárodních komisí (Mezinárodní komise pro ochranu Labe, Mezinárodní komise pro ochranu Odry před znečištěním a Mezinárodní komise pro ochranu Dunaje).

Podkladem pro zpracování plánů pro zvládání povodňových rizik jsou na úrovni plánu dílčího povodí tzv. dokumentace oblasti s významným povodňovým rizikem. Dokumentace zahrnuji jednu nebo více oblastí s významným povodňovým rizikem. Jednotlivé dokumentace jsou vždy součástí príslušného plánu dílčího povodí, ke kterému hydrologicky náleží. Dokumentace obsahují popis oblasti, její charakteristiky a zejména listy jednotlivých opatření s jejich podrobným popisem.

Nejdůležitější částí plánu pro zvládání povodňových rizik jsou kapitoly, které vytyčují cíle a popisují souhrny opatření. Cíle stanovené v rámci plánů pro zvládání povodňových rizik vycházejí ze základního požadavku směrnice 2007/60/ES snižit riziko povodní a zvýšit odolnost proti jejich negativním účinkưm na lidské zdraví, životní prostréedí, kulturní dědictví, hospodářskou činnost a infrastrukturu. Cíle zároveň respektují a navazují na cíle ochrany před povodněmi uvedené $v$ předchozích koncepčních dokumentech. $V$ souladu se současným pohledem na ochranu před povodněmi, který je též i základním principem směrnice 2007/60/ES, jsou povodně považovány za prírodní jev, kterému nelze zcela zabránit. Plány pro zvládání povodňových rizik jsou proto zaměřeny do oblasti zvládání povodňových rizik - konkrétně se jedná o 3 základní cíle:

1. zabránění vzniku nového rizika a snížení rozsahu ploch v neprijijatelném riziku,

2. snižení míry povodňového nebezpečí,

3. zvýšení odolnosti obyvatel, objektů, infrastruktury obcí a ekonomických aktivit vůči negativním účinkům povodní.

Plány pro zvládání povodňových rizik obsahují dva základní typy opatření - obecná a konkrétní. Obecná opatření slouží především k prevenci rizik a zlepšení připravenosti zvládání povodní (např. vytvoření nebo aktualizace povodňových plánů územních celků, využití výstupů povodňového mapování v územním plánování, zrízení a modernizace srážkoměrných a vodoměrných stanic, lokální výstražné systémy apod.). Obecná opatření jsou uplatňována ve všech obcích ležících v oblastech s významným povodňovým rizikem, tj. v 705 obcích (jedna "obec" od 1. 1. 2016 přestala existovat, oblast s významným povodňovým rizikem Klabava zasahovala i na území zrušeného vojenského újezdu Brdy) v povodí Labe, 216 obcích v povodí Dunaje a 69 obcích v povodí Odry.

Konkrétní opatření, kterých je celkem navrženo 52 v povodí Labe, 28 v povodí Odry a 55 v povodí Dunaje, zahrnují nejčastěji výstavbu ochranných hrází včetně mobilních prvků, suchých nádrží a prírodě blízkých protipovodňových opatření.

Návrhy plánů pro zvládání povodňových rizik byly $v$ souladu $s$ národní a evropskou legislativou připraveny ke konci roku 2014 a zveřejněny k připomínkám odborné i laické veřejnosti. Zároveň probíhalo období pro uplatnění připomínek v rámci procesu vydání plánů pro zvládání povodňových rizik opatřením obecné povahy a procesu posuzování vlivu koncepce na životní prostředí podle zákona č. 100/2001 Sb., o posuzování vlivů na životní prostředí. Většina

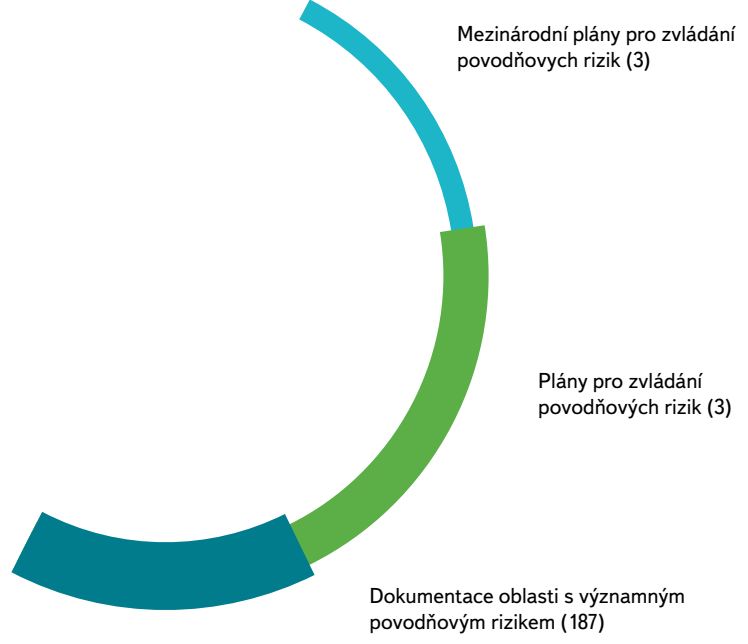

Obr. 5. Struktura plánovacích dokumentů podle Povodňové směrnice (v závorce počet pořizených dokumentů)

Fig. 5. Structure of planning documents according to Flood Directive (number of provided documents in brackets)

doručených připomínek se týkala konkrétních návrhů opatření (at̉ již návrhů na doplnění, či naopak o jejich vypuštění z návrhu plánů) a důsledného dodržování legislativy $v$ povodňové ochraně. Všechny tři dokumenty na národní úrovni (Plán pro zvládání povodňových rizik v povodí Labe, Plán pro zvládání povodňových rizik v povodí Dunaje a Plán pro zvládání povodňových rizik v povodí Odry) byly schváleny vládou ČR v prosinci 2015. MŽP plány následně vydalo opatřením obecné povahy. Plány jsou platné do roku 2021, tj. do doby schválení jejich první aktualizace, a široké veřejnosti jsou dostupné na adrese http://www.povis.cz/html/pzpr.htm.

\section{PŘEDÁVÁNÍ ZPRÁV EVROPSKÉ KOMISI}

Evropská komise požaduje po jednotlivých členských státech informace o plnění úkolů vyplývajících ze směrnice 2007/60/ES prostřednictvím zpráv, tzv. reporting. Tento reporting je třeba provést vždy do tři měsíců od termínů plnění jednotlivých úkolů. Za celé plánovací období tak bylo reportováno celkem třikrát, vždy v březnu v letech 2012, 2014 a 2016.

Informace o plnění požadavků jsou poskytovány prostřednictvím datových sad pro každou národní část mezinárodního povodí, tzn. v ČR za povodí Labe, Dunaje a Odry. Rozsah a formáty zasílaných dat jsou pro každou fázi definovány tzv. datovou šablonou. Data jsou zasílána prostřednictvím portálu Eionet (European Environment Information and Observation Network), který má nastavený systém automatických kontrol předávaných dat a za každé povodí je po úspěšném vložení dat generováno potvrzení o provedení reportingu.

$\checkmark$ rámci reportingu předběžného vyhodnocení povodňových rizik ( $v$ březnu 2012) byly do systému EK vloženy zejména prostorové informace o úsecích vodních toků vymezujících oblasti s významným povodňovým rizikem, informace o metodikách, které sloužily k tomuto vymezení, a dále informace o minulých významných povodních a o jejich následcích na lidské zdraví, kulturní dědictví, ekonomiku a životní prostředí. 
Výsledky mapování povodňového nebezpečí a povodňových rizik ( v březnu 2014) byly reportovány pouze pro scénář se středně vysokou pravděpodobností výskytu (tzn. v ČR s dobou opakování 100 let). Pro tento scénár byly Evropské komisi poskytnuty následující informace:

- orientační počet obyvatel potenciálně zasažených,

- jaké ekonomické aktivity jsou dotčeny (bydlení, infrastruktura, průmysl, zemědělství, ostatní),

— počet dotčených zařizení podle IPPC (Integrovaná prevence a omezování znečištění),

— zda jsou dotčeny chráněné oblasti uvedené v príloze IV odst. 1, bodech I, III a V směrnice 2000/60/ES o vodní politice (území pro odběr vody pro lidskou potřebu, koupací vody a území Natura 2000 a oblasti vymezené pro ochranu stanovišt').

Při reportingu plánů pro zvládání povodňových rizik v březnu 2016 nebyla na rozdíl od obou předchozích fází vyžadována žádná prostorová data. Reportovány byly souhrnné texty (Summary), ve kterých členské země popisovaly postupy a podmínky, za jakých byla navrhována opatření ke zvládání povodňových rizik $v$ oblastech $s$ významným povodňovým rizikem, a sestaveny vlastní plány. Nad rámec povinných reportingů požadovaných směrnicí 2007/60/ES byly ještě v roce 2016 plány pro zvládání povodňových rizik odeslány EK v souvislosti s požadavky evropské dotační politiky.

\section{ZÁVĚR}

Splnění úkolů uložených směrnicí 2007/60/ES znamenalo iniciaci procesu zavádění principů této směrnice do právního prostředí a institucionálního rámce České republiky. Proces byl připravován již v průběhu roku 2007 v gesci MŽP. Důležitým předpokladem pro plnění úkolů implementace byla včasná příprava metodických postupů. Návrhem objektivního postupu a vymezením oblastí s významným povodňovým rizikem pro podmínky České republiky bylo definováno zadání pro následné práce na tvorbě podkladů pro výsledné vyjádření povodňových rizik. $V$ tomto procesu byly vymezeny oblasti s významným povodňovým rizikem, které zahrnují úseky významných vodních toků v délce téměř 3 tis. km.

Pro ně bylo $v$ roce 2013 dokončeno mapování povodňového nebezpečí a povodňových rizik. Takto rozsáhlý soubor map týkající se povodňové problematiky byl v České republice vytvořen vůbec poprvé. Za nejdůležitější výstupy Ize považovat mapy povodňového ohrožení a mapy povodňových rizik. Mapy povodňového ohrožení podávají informaci o celém území dotčeném jednotlivými scénáři povodňového nebezpečí, tedy i mimo urbanizovaná území. Jsou tak vhodným podkladem pro územní plánování, protože umožňují posoudit vhodnost budoucího využití návrhových ploch. Mapy povodňového rizika pak zobrazují ty části území, které jsou vzhledem k jejich vysoké zranitelnosti chápány jako rizikové z hlediska povodní. U těchto ploch je nutné další podrobnější posouzení jejich rizikovosti z hlediska zvládání rizika.

Zmiňované mapy slouží jako podklad pro územní plánování, integrovaný záchranný systém a predevším na jejich podkladě byly zpracovány dokumentace oblastí s významným povodňovým rizikem a následně připraveny plány pro zvládání povodňových rizik v České republice. Dokumentace oblastí s významným povodňovým rizikem predstavují koncepci řešení povodňové ochrany v daném území v dlouhodobém horizontu. Plány pro zvládání povodňových rizik, schválené vládou ČR, reprezentují akční dokument obsahující návrhy opatření republikového významu, které by měly být realizovány v následujícím plánovacím období.

\section{Literatura}

[1] DRBAL, K. a kol. Návrh metodiky predběžného vyhodnocení povodñových rizikv České republice. Praha: Ministerstvo životního prostředí ČR, 2010,7s.

[2] DRBAL, K. a kol. Metodika tvorby map povodňového nebezpeči a povodňových rizik. Praha: VúV TGM Ministerstvo životního prostředí ČR, 2011, $84 \mathrm{~s}$.

[3] ANSORGE, L. Metodika pro sestavení Plánů pro zvládánípovodňových rizik. Praha: VúV TGM, Ministerstvo životního prostředí ČR, 2013, 30 s.

\section{Autoři}

Mgr. Pavla Štěpánková, Ph.D.

凶pavla.stepankova@vuv.cz

Mgr. Ing. Jana Tejkalová2

凶jana.tejkalova@mzp.cz

Ing. Karel Drbal, Ph.D.'

凶karel.drbal@vuv.cz

'Výzkumný ústav vodohospodářský T. G. Masaryka, v. v. i. ${ }^{2}$ Ministerstvo životního prostředí

Příspěvek prošel lektorským řízením.

\section{PROCESS OF IMPLEMENTATION OF DIRECTIVE 2007/60/EC ON THE ASSESSMENT AND MANAGEMENT OF FLOOD RISKS IN CONDITIONS OF THE CZECH REPUBLIC}

\section{STEPANKOVA, P.'; TEJKALOVA, J. '; DRBAL, K. ${ }^{1}$}

${ }^{1}$ TGM Water Research Institute, p. r. i.

${ }^{2}$ Ministry of Environment of the Czech Republic

Keywords: planning - floods - hazard - threat risk - area with significant flood risk - maps

The purpose of the Directive 2007/60/EC on the Assessment and Management of Flood Risks (Flood Directive) is to prevent or reduce negative consequences of floods by preparing flood risk management plans. These plans should consider individual characteristic of different areas in Europe and propose solutions according to needs and priorities those areas.

In the Czech Republic process of implementation of Flood Directive already started during preparation of this directive. There were defined main steps for implementation: (I) transposition principles of Flood Directive into legal code of the Czech Republic, (II) to develop methodical instrument to fulfil requirement of Directive. Both demanding processes were coordinated by interdepartmental working group led by Ministry of Environment.

The article introduces some of developed methodologies and their results. There is described preliminary flood risk assessment, basic methods for flood risk mapping, preparation of documentation of areas with significant flood risk and flood risk management plans. There are also mentioned obligations connected with reporting of results each steps of Flood Directive implementation. 